\title{
OBITUARIES
}

Obituaries should be submitted by email to Annabel Nicholson at annabel.nicholson@nature.com. All submitted obituaries should be 450 words maximum in length (apart from obituaries for past presidents of the BDA where the length should be 800 words).

Content of the obituary is down to the individual author, and the approval of the family should be given for the obituary prior to submission to the $B D J$.

\section{SIMON EDWARD LEWIS}

\section{5-2015}

Following a short battle with cancer, Simon Edward Lewis sadly died on January 27th 2015, aged 49.

Simon was educated at Merchant Taylors School in Liverpool, and his career in dentistry started with his studies at Bristol University in 1983. He qualified in 1988. During his undergraduate years he was actively involved with university life, holding the position of treasurer and sports representative for the student dental committee, as well as taking part in the infamous 'Dental Reviews'. He loved his outdoor activities, gaining a passion for whitewater canoeing, canoe polo, mountain biking, orienteering and walking. He was on the very first VT scheme in Carnforth, Cumbria, and published an early article in the $B D J$ describing his vocational training experience. He then went on to spend many of his early years of dentistry working as an associate in the North West of England.

Simon was wholeheartedly committed to the NHS and providing dental treatment to patients from all walks

\section{BRIAN BIRKETT}

\section{9-2015}

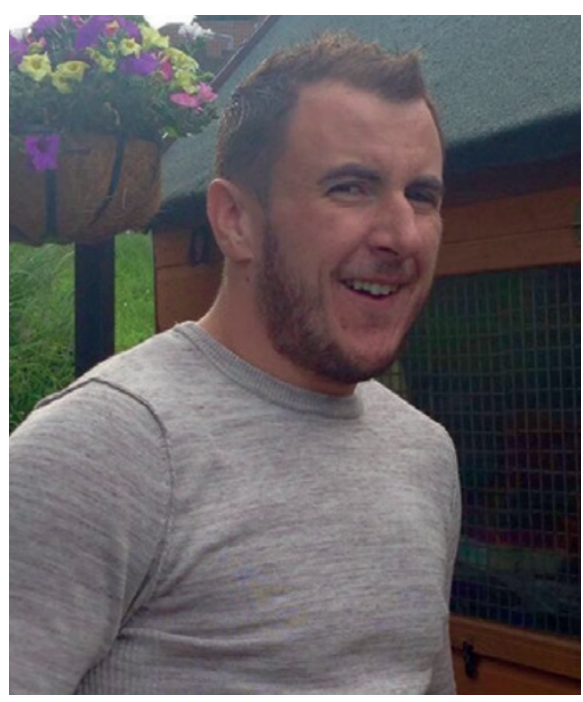

of life. In 1998 opened a 'squat' NHS Dental Practice in Ulverston, Cumbria. Shortly afterwards he was joined by his business partner Christian Turner, and together over a decade and a half, they developed the practice into a fivesurgery practice providing NHS dental care to thousands of patients across the region. Simon had a particularly caring and calming chairside manner, which eased the anxiety of many patients. He was well liked and respected by all his staff and colleagues, fun to be around, and often lifted the spirits of those he worked with. In 2009 he was appointed as a mentor with the Northern Deanery, nurturing and supporting the progress and professional development of four newly qualified NHS dentists.

Simon met his wife Sharron at Bristol University, who was nursing at that time. Following several years of world travel, they married in 1995, and moved back to the Lake District to start a family. Simon was a dedicated father to his daughters Megan and Katie, and was closely involved with their schooling, becoming school governor and later chair. He encouraged them to embrace

Brian Birkett tragically died on the morning of Saturday 11th July 2015 in a car accident, driving to his home village of Whitwell, Derbyshire. Brian was born in Sheffield and raised in the mining village where he lived with his loving, hugely proud parents, Brian and Irene - his father a retired coal miner and mother a nurse working in nearby Chesterfield. Brian qualified from the University of Sheffield in 2013.

Brian had a larger than life character and was very popular. He had huge charisma for dentistry and the social side of university life. He would often host very lively charitable events through the dental student's society in which he would entertain hundreds. At university he was hard working and

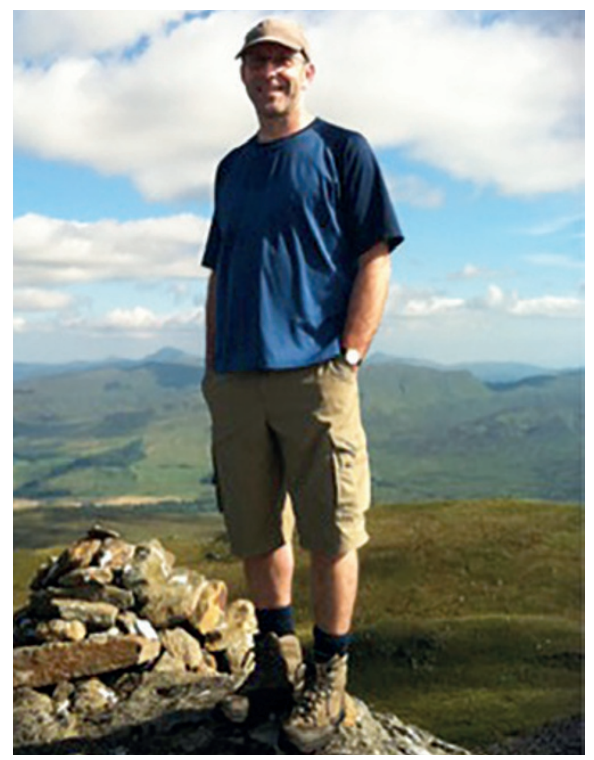

the great outdoors, as well as developing their own individuality.

Simon made a huge contribution to NHS dentistry and he will be greatly missed by his patients, his colleagues and his many friends. Our thoughts are with Sharron, Megan, Katie, his mother and father, his brother Andy, and sisters Liz and Linda.

Christian Turner

highly respected by all, coming from humble beginnings. Brian briefly moved to Cornwall for his foundation year bringing his very warm and friendly character with him. He then found work as an associate dentist in Worksop a few miles from his family home, where he thrived with his patients and fellow colleagues. He developed a keen interest in general dentistry and was planning a career in further learning. To hear laughter from his surgery was a regular occurrence.

Brian had a variety of interests including body building, cooking, cars and wrestling. The abrupt end to his very short life has been a shock to all and he will be thoroughly missed by all who knew him.

Michael Goodman 